\title{
Psychometric Evaluation of the Turkish Language Version of the Profile of Mood States (POMS)
}

\author{
Yavuz Selvi ${ }^{1}$, Mustafa Gulec ${ }^{2}$, Adem Aydin ${ }^{1}$, Lutfullah Besiroglu ${ }^{1}$
}

\section{ÖZET:}

Duygudurum Profili'nin (DP) Türkçe formunun psikometrik deg̃erlendirmesi

Amaç: Duygudurum Profili (DP) kısa süreli duygudurum deg̃ișikliklerini deg̃erlendirmek için geliștirilmiș olup 65 sıfat ve 6 alt ölçekten oluşmuștur. Çalıșmanın amacı DP'nin Türkçe Formunun çeviri yeterliḡini deg̃erlendirmek ve yöntemsel hataların üstesinden gelinmesindeki karar alma süreçlerini bildirmekti.

Yöntem: İngilizce Form Türkçeye uzman ekip yaklaşımı ile çevrildi. Geri çeviri, iki dilli öznelerin kullanımı ve eș zamanlı geçerlik için dig̃er ölçekler ile bag̃ıntı gibi dig̃er tekniklere ilaveten yapı geçerlig̃i için ag̃ılıklı olarak faktör analizi kullanıldı.

Bulgular: Elli sekiz maddelik Türkçe formun son hali uygun psikometrik özelliklere sahipti. Türk katılımcıların verilerine dayanan bulgularımız 6 faktörlü orijinal çözümü tekrarladı ("çökkünlük-keyifsizlik"-15, "gerginlik-sıkıntı"-9, "öfke-saldırganlık"-12, "şaşkınlık-şaşırmışlık "-7, "yorgunluk-durgunluk "-7 ve "dinçlik-aktiflik"-8). Uygun bir kalıba ulaşmak için hiçbir faktöre uymayan 7 maddeyi dışlamak gerekti. Bu sonuçları sag̃lama örneklemi üzerinde dog̃rulayıcı bir faktör analizi yürüterek ve karșılaștırılabilir bir kalıp ve yine karşılaştırılabilir faktör yükleri elde ederek sınadık. Bu formun eș zamanlı geçerliği DP alt ölçek puanları ile anksiyete ve depresyon ölçek puanları arasındaki bag̃ıntılar aracilıg̃ılla kanıtlandı.

Sonuçlar: Çalışma geçerli psikometrik özellikler göstermesine karşın ölçeg̃in duyarlıg̃ını deg̃erlendirmek için çeșitli topluluklarda yapılmıș daha ileri çalışmalara ihtiyaç vardır.

Anahtar sözcükler: psikometrik, türkçe, profil, duygudurum, geçerlik, güvenirlik

Journal of Mood Disorders 2011;1(4):152-61

\section{ABSTRACT:}

Psychometric evaluation of the Turkish language version of the Profile of Mood States (POMS)

Aim: The POMS was developed to assess short-term mood changes and consisted of 65 adjectives and 6 subscales. The purpose of the study was to assess the translation adequacy of a Turkish version of the POMS, and to report the decision-making process of overcoming methodological faults.

Method: The English version was translated to Turkish by expert team approach. Factor analysis for construct validation was predominantly used for assessment, in addition to other techniques: back translation, use of bilingual subjects, and correlation with other instruments for concurrent validation.

Results: The final 58-item Turkish version has suitable psychometric properties. Our findings, based on data from Turkish participants, replicated the original 6-factor solution ("depression-dejection"-15, "tension-anxiety"-9, "anger-hostility"-12, "confusion-bewilderment"-7, "fatigue-inertia"-7, and "vigor-activity"-8). To achieve an acceptable fit, it was necessary to omit 7 items that did not fit any factor. We verified these results by conducting a confirmatory factor analysis on the validation sample and obtaining comparable fit and comparable factor loadings. The concurrent validity of this form was evidenced by the correlations between scores from the POMS subscales and scores from measures of anxiety and depression.

Conclusions: Although the study shows valid psychometric properties, further studies made in various populations are needed to assess the sensitivity of the scale.

Key words: psychometric, turkish, profile, mood, validity, reliability

Journal of Mood Disorders 2011;1(4):152-61
${ }^{1} \mathrm{MD}$, Department of Psychiatry, Faculty of Medicine, Yuzuncu Yil University, Van-Turkey ${ }^{2} \mathrm{MD}$, Department of Psychiatry, Faculty of Medicine, Ataturk University, Erzurum-Turkey

Yazıșma Adresi / Address reprint requests to: Mustafa Gulec, Department of Psychiatry, Faculty of Medicine, Ataturk University, Erzurum-Turkey

Elektronik posta adresi / E-mail address: mustafagulec78@yahoo.com

Kabul tarihi / Date of acceptance: 2 Eylül 2011 / September 2, 2011

\section{Bag̃ıntı beyanı}

Y.S., M.G., A.A., L.B.: Yazarlar bu makale ile ilgili olarak herhangi bir çıkar çatışması bildirmemişlerdir.

Declaration of interest:

Y.S., M.G., A.A., L.B.: The authors reported no conflict of interest related to this article.

\section{INTRODUCTION}

Reliable and valid rating scales have greatly advanced research on mood disorders and offer potential means of improving routine clinical assessment. Formal rating scales generally accomplish a simple objective: by digitizing clinical phenomena on ordinal scales, scales allow tracking of symptom clusters over time (1). The aims of the rating scales can be listed as follows: 'screening for presence of psychiatric disorders', 'classifying and diagnosing psychiatric disorders,' and 'measuring changes in psychopathology.' These scales, which provide the option to evaluate the mood and psychological changes, can be prepared in the form of clinician rated or self rated scales (2).

Mood may be defined as pervasive and sustained tone of emotions. It is subjectively experienced and reported by a person and observed by others; examples include 
depression, elation, or anger. Generally, mood appears to influence the way people perceive, interpret, plan, and execute strategic interpersonal behaviours and thereby influence the kind of social information (3). Mood lability and mixtures of moods are important clinical features that may contribute to diagnostic formulation and treatment response (4). Therefore it is absolutely necessary to determine these mood states for correct diagnosis and treatment.

The measurement of mood and many other psychological variables are typically conducted by using self-report assessment instruments. These types of measures are also considered to be the most efficient and the easiest measures to administer (5). The POMS is one of these scales. POMS was developed by McNair, Lorr, and Droppleman (1971) to assess transient distinct mood states rapidly and reliably (6). It can be used for assessing psychiatric patients and their responses to various therapeutic approaches. POMS has also been used to measure the effects of various experimental manipulations performed on normal subjects and other non-psychiatric populations.

Although a number of alternate language forms of the POMS exist, including Arabic (7), German (8), Chinese (9), Dutch (10), Spanish (11), French (12), Korean (13), Hebrew (14) and Japanese (15) group-specific evaluations are needed for additional alternate language versions.

POMS was also used in many different studies. Some examples are as follows: 1 . Studies related with sleep, sleep deprivation, and dreams $(16,17) .2$. Affect and cognition in dreams (18). 3. Studies aimed to evaluate the short and long term effects of pharmacotherapy, psychotherapy, and other therapies (19-21). 4. Studies about the relationships between physiological and biological variables and mood changes (22-24). 5. Some studies about the mood changes after the various practices $(25,26)$.

A number of shorter forms of the POMS have also been developed using various subsets of items from the original POMS. Typically, the subsets were derived either by dropping items that had low factor loadings or dropping items that would improve the internal consistency reliability of a subscale (8-10,12,13,27-31). In alternate language short forms, items that posed translation or comprehension problems were also dropped $(8-10,12,13,27,29)$. The short versions we could locate had from 22 to 48 items. All but two of these shorter versions excluded the friendliness items $(13,29)$.
Although a few mood scales were examined for reliability and validity in Turkey previously, there is no scale available that measures the short-term and situational mood changes. In the present study we assessed the reliability and validity of the Turkish version of the POMS. One way to overcome methodological errors and to ensure optimal translation is to combine several assessment techniques while performing the translation procedures $(32,33)$. Due to the unique difficulty involved in translating a multi-dimensional, single-word item questionnaire, in the present paper we implemented a number of techniques. Furthermore, we used the expert team approach in the first few steps of translation and the committee approach in the advanced steps, following the initial procedure of pre-testing.

\section{METHOD}

\section{The Participants}

1. Twenty English teachers, aged 25-45, men and women native English speakers, who live in Turkey, mostly in Istanbul and possess very superior command of the Turkish language.

2. Three groups of students (Group 1: N=101, Group 2: $\mathrm{N}=124$, Group 3: N=113) from the Yuzuncu Yil University School of Medicine aged $22.1( \pm 2.2)$. The groups included approximately $60 \%$ males aged $23( \pm 2.2)$ and $40 \%$ females aged $21.6( \pm 2.1)$. The mean age and gender distribution of the groups were quite typical to the mean age and gender distribution of students at the Yuzuncu Yil University School of Medicine. All three groups were tested during first or second grade. All students were assessed for any psychiatric disorder by using the Structured Clinical Interview for DSM-IV Axis I Disorders, Clinician Version (SCID-I, CV) $(34,35)$ and the Structured Clinical Interview for DSM-IV Axis II Personality Disorders (SCID-II) $(36,37)$. The SCIDs were administered by a trained psychiatric clinician with minimum 2 years of experience in the relevant field. Mentally healthy students (no psychiatric diagnosis on Axis I or II) were accepted.

3. Two groups of patients who were seen at psychiatric outpatients clinics of the Yuzuncu Yil University School of Medicine. The group A (N=111), which included approximately $40 \%$ males aged $26.2( \pm 7.5)$ 
and $60 \%$ females aged $30( \pm 9.9)$ years old, consisted of patients who had an anxiety disorder other than acute or post-traumatic stress disorder. The group $\mathrm{D}(\mathrm{N}=109)$, which included approximately $35 \%$ males aged 28.2 $( \pm 8.1)$ and $65 \%$ females aged $35.2( \pm 9.2)$ years old, consisted of patients who met major depressive disorder criteria. Both groups were tested in one of the psychiatric outpatient clinics of the Yuzuncu Yil University School of Medicine. The diagnoses of patients were confirmed with the DSM-IV-TR criteria in conjunction with SCID-I interviews. Also, they were confirmed to have no psychiatric diagnosis on Axis II by means of SCID-II. The SCIDs herewere administered by the same trained psychiatrist. The patients were not taking any psychotropic drugs before and during the evaluations, so the test results were not affected.

Common exclusion criteria were as follows for all participants (clinical or non-clinical): (a) having a personality disorder; (b) presence of the psychoactive substance or alcohol abuse or dependence; (c) having a circadian rhythm sleep disorder; (d) presence of the drug(s) influencing mood and emotions; (e) presence of a condition that may influence the circadian rhythm like shift work or jet lag; (f) existence of a chronic medical illness; and (g) being out of the 18-50 age interval.

The data used for this study were collected between January 2006 and January 2008. All participants were informed about the aims of the study and their written consents were obtained. They were not compensated in any way for their participation. A totally voluntary contribution mechanism was used. To encourage honesty, objectivity, and precision in completing the questionnaires, the identity of the participants was kept confidential. To achieve objectivity, participants were asked to record their true feelings rather than how they thought they were "supposed" to feel. This study was approved by the Ethics Committee of the Faculty of Medicine, Yuzuncu Yil University of Van.

\section{INSTRUMENTS}

\section{The Profile of Mood States (POMS)}

POMS is a self-rating scale which consisted of 65 adjectives that were rated on a 5-point scale. The scale begins with the instruction of: "Below is a list of words that describe feelings people have. Please read each one carefully, then fill in one space under the answer to the right which best describes how you have been feeling during the past week including today (or today, right now, and even the past three minutes). The numbers refer to the following descriptive phrases.

$0=$ not at all

$1=\mathrm{a}$ little

$2=$ moderately

$3=$ quite a bit

$4=$ extremely

POMS measures 6 identifiable mood or affective states: "tension-anxiety”, “depression-dejection”, "angerhostility", "vigor-activity", "fatigue-inertia" and "confusion-bewilderment". To obtain a score for each mood factor, the sum of the responses is obtained for the adjectives defining the mood factor. A seventh score of Total Mood Disturbance is also calculated by subtracting the score on the one positively scored subscale, vigoractivity, from the sum of the other five subscales (see Appendix 1 for further information).

\section{The Beck Anxiety Inventory (BAI)}

In this 21-item scale (38), test takers are asked "How have been feeling during the past week, including today" on a four point scale ranging from "not at all" to "very much so." The psychometric properties of this scale are well established. It was adapted to Turkish by Ulusoy, Sahin, and Erkmen (1998) and has been widely used in Turkey (39). High values of reliability and validity have been found in the Turkish version.

\section{The Beck Depression Inventory (BDI)}

This scale consists of 21 self-descriptive items (40). Every item contains 4 sentences. Respondents are asked to check the sentences that are descriptive of "How you have been feeling during the past week including today". The score is the sum of the selected sentences (range 0-63). The scale was adapted to Turkish by Hisli (1989) and has been widely used by the researchers in psychiatry and psychology in Turkey (41). The Turkish version has yielded high values of reliability and validity. 


\section{Procedure}

Three native English speakers translated the original English version of the POMS separately (expert team approach) to Turkish. All three possessed a very good command of the Turkish language and each one of them translated all 65 adjectives in the POMS choosing the most fitting adjective in Turkish. In cases of equivalence between at least two, the translation of that adjective was accepted. In cases where three different words were offered, a researcher with exceptional command of English and Turkish, as well as considerable knowledge and research experience in exercise psychology, served as a judge and made a final decision.

In the following stage, two additional bilingual persons translated the Turkish version back into English. The backtranslations were then compared to the original English version. The back translation procedure resulted in exactly the same items in English as the original version. All 65 items were equivalent in the original Turkish translation, thus two back translations were found valid. For this reason, the original Turkish translation remained unchanged.

Both versions, the English and the Turkish, were administered among the English teachers. They were randomly divided into two groups. One group filled in the Turkish version first, followed by the English one, while the other group received the English first, followed by the Turkish version.

The Turkish version was then administered to students from Group 1. We performed a confirmatory factor analysis on the data and were able to yield the same 6 factors (Depression-dejection, tension-anxiety, angerhostility, confusion-bewilderment, fatigue-inertia, and vigor-activity subscales) as in the original English version.

A committee was then formed (committee approach) comprisinga clinical psychologistand two methodologists, all possessing superior command of English and Turkishand who reached the final decision that both versions (English and Turkish) measure the same components and it means that the Turkish version is valid. Secondly, the committee omitted 7 items (friendly, clear-headed, considerate, sympathetic, helpful, goodnatured, and trusting) as they did not fit any factor. The final Turkish version, then, included 58 items, distributed among the factors as follows: "depression-dejection"-15, "tension-anxiety"-9, "anger-hostility"-12, "confusion- bewilderment"-7, "fatigue-inertia"-7, and "vigoractivity"-8. Group 2 and 3 took the final version of the POMS as well as the BAI and the BDI. The three questionnaires were administered in random order. Some students took the POMS first, followed by the BAI, followed by the BDI, while others took the BAI first, followed by the POMS and then the BDI, etc. Group A took the final version of the POMS, along with the BAI. Similarly, Group D took the final version of the POMS, along with the BDI.

\section{Data Analysis}

Because of the recommended procedure for evaluating reliability (and validity) is to have bilingual participants fill out the questionnaire in both languages and assess the correlation between the two, scores of the final version of the POMS were compared between the English and Turkish versions taken by the bilingual teachers, and the percent of equivalence was calculated.

For the validity, suitable procedure is to perform a factor analysis on the findings. For this, all participants (clinical or non-clinical) can be included in the analysis. If this analysis produces the same 6 factors as in the English version, it will mean that both versions measure the same components and the Turkish version is valid enough. So, Principal Axis (exploratory) Factor analysis (PAF), with varimax rotation, was conducted on the final version of the POMS in Group 2, in Group 3, in Group A, and in Group D. The inclusion criterion loading was 0.40 .

Cronbach's Alpha is a proper way to assess internal consistency that provides some indication of reliability. Thus, this technique was applied in all groups and provided separate alphas for each subscale.

Another way of validating the test is to administer another instrument together with the POMS, one that has already been used and established in Turkish, for example, a depression scale. If the correlation between the depression-dejection subscale of the POMS and the 2nd depression scale is high, this consequence will provide some indication of validity of the Turkish version of the POMS. It's called external validation. For this purpose, a Pearson correlation was conducted between the "depression-dejection" factor of the POMS and the BDI in groups 2, 3, and D and between the "tension-anxiety" factor of the POMS and the BAI in groups 2, 3, and A. 
Table 1: Exploratory Factor Analyses of the 58 Items of the PoMS in four Turkish Groups (In Turkish)

\begin{tabular}{|c|c|c|c|c|c|}
\hline \multirow[b]{2}{*}{ Factors } & \multirow[b]{2}{*}{ Items } & \multicolumn{4}{|c|}{ Factor Loadings in Four Groups } \\
\hline & & Group 2 & Group 3 & Group A & Group D \\
\hline \multicolumn{6}{|l|}{ Depression-dejection } \\
\hline \multirow[t]{15}{*}{$(d-d)$} & Unhappy & 0.70 & 0.66 & 0.74 & 0.69 \\
\hline & Sorry for things done & 0.57 & 0.56 & 0.58 & 0.61 \\
\hline & Sad & 0.65 & 0.61 & 0.68 & 0.57 \\
\hline & Blue & 0.69 & 0.81 & 0.78 & 0.71 \\
\hline & Hopeless & 0.75 & 0.71 & 0.66 & 0.77 \\
\hline & Unworthy & 0.73 & 0.72 & 0.82 & 0.81 \\
\hline & Discouraged & 0.83 & 0.76 & 0.78 & 0.86 \\
\hline & Lonely & 0.77 & 0.60 & 0.67 & 0.61 \\
\hline & Miserable & 0.73 & 0.73 & 0.80 & 0.76 \\
\hline & Gloomy & 0.69 & 0.79 & 0.61 & 0.81 \\
\hline & Desperate & 0.72 & 0.75 & 0.84 & 0.77 \\
\hline & Helpless & 0.82 & 0.69 & 0.79 & 0.71 \\
\hline & Worthless & 0.76 & 0.71 & 0.72 & 0.72 \\
\hline & Terrified & 0.83 & 0.74 & 0.84 & 0.79 \\
\hline & Guilty & 0.84 & 0.83 & 0.80 & 0.80 \\
\hline \multicolumn{6}{|l|}{ Tension-anxiety } \\
\hline \multirow[t]{9}{*}{$(\mathrm{t}-\mathrm{a})$} & Tense & 0.84 & 0.72 & 0.79 & 0.73 \\
\hline & Shaky & 0.73 & 0.67 & 0.76 & 0.71 \\
\hline & On edge & 0.83 & 0.68 & 0.61 & 0.61 \\
\hline & Panicky & 0.66 & 0.61 & 0.70 & 0.62 \\
\hline & Relaxed & 0.79 & 0.74 & 0.71 & 0.75 \\
\hline & Uneasy & 0.69 & 0.63 & 0.81 & 0.71 \\
\hline & Restless & 0.78 & 0.76 & 0.77 & 0.73 \\
\hline & Nervous & 0.71 & 0.73 & 0.73 & 0.70 \\
\hline & Anxious & 0.84 & 0.80 & 0.80 & 0.84 \\
\hline \multicolumn{6}{|l|}{ Anger-hostility } \\
\hline \multirow[t]{12}{*}{$(a-h)$} & Angry & 0.68 & 0.74 & 0.63 & 0.62 \\
\hline & Peeved & 0.76 & 0.71 & 0.71 & 0.73 \\
\hline & Grouchy & 0.85 & 0.75 & 0.76 & 0.79 \\
\hline & Spiteful & 0.79 & 0.71 & 0.81 & 0.75 \\
\hline & Annoyed & 0.71 & 0.64 & 0.69 & 0.64 \\
\hline & Resentful & 0.80 & 0.78 & 0.83 & 0.79 \\
\hline & Bitter & 0.71 & 0.67 & 0.69 & 0.72 \\
\hline & Ready to fight & 0.75 & 0.71 & 0.74 & 0.77 \\
\hline & Rebellious & 0.65 & 0.59 & 0.62 & 0.60 \\
\hline & Deceived & 0.63 & 0.64 & 0.80 & 0.76 \\
\hline & Furious & 0.63 & 0.69 & 0.60 & 0.71 \\
\hline & Bad-tempered & 0.77 & 0.72 & 0.70 & 0.73 \\
\hline \multicolumn{6}{|l|}{ Confusion-bewilderment } \\
\hline \multirow[t]{6}{*}{$(c-b)$} & Confused & $\begin{array}{l}0.73 \\
079\end{array}$ & 0.61 & 0.68 & 0.62 \\
\hline & $\begin{array}{l}\text { Unable to concentrate } \\
\text { Muddled }\end{array}$ & $\begin{array}{l}0.79 \\
0.59\end{array}$ & $\begin{array}{l}0.85 \\
0.58\end{array}$ & $\begin{array}{l}0.80 \\
0.58\end{array}$ & $\begin{array}{l}0.81 \\
0.53\end{array}$ \\
\hline & Bewildered & 0.62 & 0.78 & 0.84 & 0.65 \\
\hline & Efficient & 0.57 & 0.50 & 0.61 & 0.56 \\
\hline & Forgetful & 0.73 & 0.65 & 0.63 & 0.62 \\
\hline & Uncertain about things & 0.74 & 0.70 & 0.71 & 0.71 \\
\hline \multicolumn{6}{|l|}{ Fatigue-inertia } \\
\hline \multirow[t]{7}{*}{$(f-i)$} & Worn out & 0.74 & 0.71 & 0.78 & 0.76 \\
\hline & Listless & 0.53 & 0.57 & 0.50 & 0.53 \\
\hline & Fatigued & 0.81 & 0.79 & 0.79 & 0.80 \\
\hline & Exhausted & 0.84 & 0.80 & 0.81 & 0.81 \\
\hline & Sluggish & 0.69 & 0.85 & 0.77 & 0.81 \\
\hline & Weary & 0.69 & 0.62 & 0.63 & 0.66 \\
\hline & Bushed & 0.61 & 0.64 & 0.70 & 0.69 \\
\hline \multicolumn{6}{|l|}{ Vigor-activity } \\
\hline$(v-a)$ & Lively & 0.65 & 0.72 & 0.59 & 0.64 \\
\hline & Active & 0.84 & 0.77 & 0.80 & 0.82 \\
\hline & Energetic & 0.71 & 0.71 & 0.82 & 0.81 \\
\hline & Cheerful & 0.66 & 0.61 & 0.69 & 0.61 \\
\hline & Alert & 0.85 & 0.86 & 0.75 & 0.80 \\
\hline & Full of pep & 0.79 & 0.77 & 0.71 & 0.74 \\
\hline & Carefree & 0.70 & 0.73 & 0.74 & 0.72 \\
\hline & Vigorous & 0.69 & 0.67 & 0.70 & 0.70 \\
\hline
\end{tabular}


Table 2: Internal Consistency Scores (Cronbach's $\alpha$ ) for the Factors

\begin{tabular}{ccccccc} 
Factors & $\begin{array}{c}\text { Bilinguals } \\
\text { (Turkish) } \\
\mathbf{N = 2 0}\end{array}$ & $\begin{array}{c}\text { Bilinguals } \\
\text { (English) } \\
\text { N=20 }\end{array}$ & $\begin{array}{c}\text { Group 2 } \\
\mathbf{N = 1 2 4}\end{array}$ & $\begin{array}{c}\text { Group 3 } \\
\mathbf{N = 1 1 3}\end{array}$ & $\begin{array}{c}\text { Group A } \\
\mathbf{N = 1 1 1}\end{array}$ & $\begin{array}{c}\text { Group D } \\
\mathbf{N = 1 0 9}\end{array}$ \\
\hline d-d & 0.85 & 0.86 & 0.88 & 0.86 & 0.87 & 0.91 \\
t-a & 0.86 & 0.88 & 0.87 & 0.85 & 0.90 & 0.91 \\
a-h & 0.90 & 0.87 & 0.81 & 0.83 & 0.89 & 0.89 \\
c-b & 0.84 & 0.88 & 0.83 & 0.81 & 0.90 & 0.81 \\
f-i & 0.81 & 0.82 & 0.88 & 0.83 & 0.84 & 0.91 \\
v-a & 0.81 & 0.88 & 0.91 & 0.83 & 0.82 & 0.87
\end{tabular}

\section{RESULTS}

Comparing the scores of the English and the Turkish version (the final version), taken by the bilingual teachers, provided the following results: Complete agreement or a one grade difference between the two languages was reported among over $90 \%$ of the participants on 46 items, between 80 to $89 \%$ on 10 items, and between 70 to $79 \%$ on 2 items.

Results of the factor analyses are presented in Table 1.

The variance accounted for in Group $2(\mathrm{~N}=124)$ was $68.6 \%$, in Group $3(\mathrm{~N}=113) 67.9 \%$, in Group A ( $=111)$ $68.4 \%$, and in Group D ( $\mathrm{N}=109) 68.1 \%$. All items in groups had a load of more than 0.4 on the factors.

Table 2 presents reliability values (Cronbach's $\alpha$ ) of each factor on all groups.

The results of the Pearson correlation between the "depression-dejection" factor of the POMS and the score on the BDI was $0.78(\mathrm{p}<0.001)$ in Group $2(\mathrm{~N}=124), 0.76$ $(\mathrm{p}<0.001)$ in Group $3(\mathrm{~N}=113)$, and $0.79(\mathrm{p}<0.001)$ in Group $\mathrm{D}(\mathrm{N}=109)$. The correlation between the "tension-anxiety" factor of the POMS and the BAI was $0.73(\mathrm{p}<0.001)$ in Group $2(\mathrm{~N}=124), 0.71(\mathrm{p}<0.001)$ in Group $3(\mathrm{~N}=113)$, and $0.74(\mathrm{p}<0.001)$ in Group A $(\mathrm{N}=111)$.

\section{DISCUSSION}

Our findings, based on data from Turkish participants, replicated the original 6 -factor solution proposed by McNair et al. (1971) (6). To achieve an acceptable fit, it was necessary to omit some items that did not fit any factor. We verified these results by conducting a confirmatory factor analysis on the validation sample and obtaining comparable fit and comparable factor loadings. The concurrent validity of this form was evidenced by the correlations between scores from the POMS subscales (depression-dejection, tension-anxiety) and scores from measures of anxiety (BAI) and depression (BDI). The results of the present study suggest that the 58-item Turkish version of the POMS has a stable structure in assessing discrete dimensions of mood. Following a process of methodological and conceptual assessment, factor analysis was conducted on four different Turkish speaking groups. Two of these groups were clinical. The results consistently indicated the following 6 dimensions: "depression-dejection"-15, "tension-anxiety"-9, "anger-hostility"-12, "confusionbewilderment"-7, "fatigue-inertia"-7, and "vigoractivity"-8. In addition, internal consistency, assessed in all groups, yielded satisfactory results. The final stage of the process included measuring concurrent validation by comparing results of specific factors to other scales measuring equivalent constructs. Results of those comparisons were highly suitable as well.

Both the original and the various shorter versions of the POMS are generally considered to be reliable and valid, with very good to excellent internal consistency reliability and/or support for concurrent or discriminant validity $(27,42-44)$. Yet, a search combining test evaluation terms (e.g., reliability, psychometric, construct validity) with the POMS yielded only 14 -factor analytic studies subsequent to the initial factor analyses conducted in 1971 by McNair and colleagues (7-11,42,45-51).

Overall, our findings were consistent with five of these 14 studies that supported the original 6-factor structure identified in $1971(8,42,45,46)$. Three of these five studies were short versions of the POMS, including a German language version (8), an English language version (42), and an Arabic language version (7). The remaining two studies were English language versions of the original 
65-item POMS $(45,46)$

Boyle (1987) investigated further the factorial structure of the POMS in an Australian college sample of 289 undergraduate students (45). Responses for all 65 items were inter-correlated and subjected to an iterative principal factoring procedure together with rotation to oblique simple structure. He found high correlations among the 6 POMS subscales. Results indicated that the basic subscale structure of the profile is reliable. Gibson (1997) examined the reliability and validity of the POMS questionnaire when administered to 479 communitydwelling older adults (46). Factor analysis replicated the original factor structure identified in young-adult samples, suggesting that older adults adopt the same underlying constructs of mood when responding to the POMS. There was strong support for concurrent validity, and this instrument was able to discriminate between healthy adults and patients with known mood disturbance. Excellent internal consistency of POMS subscales and very good retest reliability were noted.

Our findings were similar to those of Boyle and Gibson $(45,46)$. However, the committee omitted 7 items (friendly, clear-headed, considerate, sympathetic, helpful, goodnatured, and trusting) that did not fit any factor in the present study. This was demonstrated also in the original study of McNair et al (1971). On the contrary, muddled and efficient items were problematic in the studies of these investigators. But all groups had a load of more than 0.40 on mentioned items in our study. The adjectives and phrases on the POMS were constructed from a word list published in 1944 (52), and terms like muddled, for example, might have become archaic over time (53). Current Turkish equivalents might be more understandable of these adjectives.

Our findings also point out that translating psychological assessment devices from one language to the other is not just a matter of finding the right words. It should involve, in addition to literal translation, a process of revision, modification, and amendment of the content of those devices to fit the receiving culture.

Besides, including not only the healthy adults $(45,46)$ but also the clinical participants (psychiatric outpatients) was an important advantage in the present study. Because of the POMS is a very sensitive scale (assessing mood "last week including today"), stability of scores on two different dates should not be expected too much. So, test-retest does not seem to be an appropriate method to assess reliability in the present study. In contrast to Gibson (1997), test-retest reliability was not examined (46).

Based on findings from this study, researchers can use the Turkish POMS with confidence to assess mood in Turkish-speaking clinical and research populations. The long form not only demonstrated evidence of acceptable reliability and validity, but it is also less burdensome for respondents. The benefit of having a Turkish language version of a widely used measure like the POMS is that it allows comparing mood states across different cultural groups. A disadvantage, however, is that the POMS may omit mood states and symptoms that are specific to Turks. One limitation of this study is that the sample was particularly young or middle-aged adults. It is possible that a different factor structure would be obtained from older adults. However, age differences in the factor structure of the POMS have not been prominent in the mentioned study (46). A combined qualitative and quantitative research design is also needed to provide an insider perspective on the multi-dimensional nature of the POMS. For example, a Q sort of the POMS items would provide respondents' perceptions of which items reflect which mood states. Open-ended interview questions that explore mood states and symptoms that are salient to Turks and perhaps missing from the POMS, would also contribute to more complete mood assessments in this population.

Finally, as we chose to perform the initial pretesting of the Turkish version on homogeneous groups we used students only. Although our study shows valid psychometric properties, further testing of the Turkish version is recommended on various populations such as different age groups, or psychiatric inpatients. In addition, further studies are needed to assess the sensitivity of the subcomponents in the Turkish version to diverse manipulations in psychiatry, in anxiety and mood disorders and in other fields. 


\section{References:}

1. Sachs GS, Guille C, McMurrich SL. A clinical monitoring form for mood disorders. Bipolar Disord 2002; 4: 323-327.

2. Dennis M, Ferguson B, Tyrer P. Rating instruments. In Research Methods in Psychiatry: A Beginner's Guide, Freeman C, Tyrer P (editors). Second ed., London: Royal College of Psychiatrist, 1995: 98-134.

3. Argus GR, Terry FC, Bramston F, Dinsdale SL. Measurement of mood in adolescents with intellectual disability. Res Dev Disabil 2004; 25: 493-507.

4. Little K, Penman A. Measuring subacute mood changes using the profile of mood states and visual analogue scales. Psychopathology 1989; 22: 42-49.

5. Watson D. Mood and Temperament. First ed., New York: Guilford Press, 2000.

6. McNair DM, Lorr M, Droppleman LF. Manual for the Profile of Mood States. First ed., San Diego: Educational and Industrial Testing Service, 1971

7. Aroian KJ, Kulwicki A, Kaskiri EA, Templin TN, Wells CL. Psychometric evaluation of the Arabic language version of the Profile of Mood States. Res Nurs Health 2007; 30: 531-541.

8. Bullinger $M$, Heinisch $M$, Ludwig $M$, Geier S. Scales for the assessment of emotional well-being: Psychometric analysis of the Profile of Mood States (POMS) and of the Psychological General Well-Being Index (PGWI). Zeischrift fur Differentielle und Diagnostische Psychologie 1990; 11: 53-61.

9. Chen KM, Snyder M, Krichbaum K. Translation and equivalence: The Profile of Mood States Short Form in English and Chinese. Int J Nurs Stud 2002; 39: 619-624.

10. De Groot MH. Psychometric characteristics of a mood states inventory: Shortened POMS. Gedrag Gezond 1991; 20: 46-51.

11. Fernandez CA, Fernandez EMA, Pesqueira GS. Semantic problems in adapting the POMS in to Spanish. Psicothema 2000; 14: 47-51.

12. Fillion L, Gagnon P. French adaptation of the shortened version of the Profile of Mood States. Psychol Rep 1999; 84: 188-190.

13. Shin Y, Colling KB. Cultural verification and application of the Profile of Mood States (POMS) with Korean elders. West J Nurs Res 2000; 22: 68-83.

14. Netz Y, Zeav A, Arnon M, Daniel S. Translating a single-word items scale with multiple subcomponents-A Hebrew translation of the Profile of Mood States. Isr J Psychiatry Relat Sci 2005; 42: 263-270.

15. Yokoyama K, Araki S, Kawakami N, Tkakeshita T. Production of the Japanese edition of profile of mood states (POMS): assessment of reliability and validity. Nippon Koshu Eisei Zasshi 1990; 11: 913918.

16. Lewis KE, Blagrove M, Ebden P. Sleep deprivation and junior doctors' performance and confidence. Postgrad Med J 2002; 78: 85-87.

17. Kamdar BB, Kaplan KA, Kezirian EJ, Dement WC. The impact of extended sleep on daytime alertness, vigilance and mood. Sleep Med 2004; 5:441-448.
18. Newel PT, Cartwright RD. Affect and cognition in dreams: A critique of the cognitive role in adaptive dream functioning and support for associative models. Psychiatry 2000; 63: 34-44.

19. Szuba MP, O'Reardon JP, Rai AS, Snyder-Kastenberg J, Amsterdam JD, Gettes DR. Acute mood and thyroid stimulating hormone effects of transcranial magnetic stimulation in major depression. Biol Psychiatry 2001; 50: 22-27.

20. Barbano RL, Herrmann DN, Hart-Gouleau S, Pennella-Vaughan J, Lodewick PA, Dworkin RH. Effectiveness, tolerability, and impact on quality of life of the \%5 lidocaine patch in diabetic polyneuropathy. Arch Neurol 2004; 61: 914-918.

21. Yu BH, Israel SA, Dimsdale JE. Effect of CPAP treatment on mood states in patients with sleep apnea. J Psychiatr Res 1999; 33: 427-432.

22. Van Goozen SH, Wiegant VM, Endert E, Helmond FA, Van de Poll NE. Psychoendocrinological assessment of the menstrual cycle: The relationship between hormones, sexuality and mood. Arch Sex Behav 1997; 359-364.

23. Hohlagschwandtner M, Husslein P, Klier C, Ulm B. Correlation between serum testosterone levels and peripartal mood states. Acta Obstet Gynecol Scand 2001; 80: 326-330.

24. Nasta MT, Grussu P, Quatraro RM, Cerutti R, Grella PV. Cholesterol and mood states at 3 days after delivery. J Psychosom Res 2002; 52: 61-63.

25. Woolery A, Myers H, Sternlieb B, Zeltzer L. A yoga intervention for young adults with elevated symptoms of depression. Altern Ther Health Med 2004; 10: 60-63.

26. Kenny TD, Faunce G. The impact of group singing on mood, coping, and perceived pain in chronic pain patients attending a multidisciplinary pain clinic. J Music Ther 2004; 3: 241-258.

27. Cheung SY, Lam ET. An innovative shortened bilingual version of the Profile of Mood States (POMS-SBV). Sch Psychol Int 2005; 26: 121-128.

28. Grove JR, Prapavessis H. Preliminary evidence for the reliability and validity of an abbreviated Profile of Mood States. Int J Sport Psychol 1992; 23: 93-109.

29. Fernandez EMA, Fernandez CA, Pesqueira GS. Adaptation of the Profile of Mood States into Spanish with a sample of athletes. Psicothema 2002; 14: 708-713.

30. McNair DM, Heuchert JWP. Profile of Mood States (POMS): Technical update. First ed., New York: Multi-Health Systems Incorporated, 2003.

31. Shacham S. A shortened version of the Profile of Mood States. J Pers Assess 1983; 47: 305-306.

32. Brislin RW. Back-translation for cross-cultural research. J Cross Cult Psychol 1970; 1: 185-216.

33. Harkness J. Questionnaire translation. In Cross-cultural Survey Methods, Harkness J, van de Vijver FJR, Mohler PP (editors). First ed., New Jersey: Wiley, 2003: 35-57.

34. First MB, Spitzer RL, Gibbon M, Williams JBW. Structured Clinical Interview for DSM-IV Axis I Disorders (SCID-I), Clinical Version. First ed., Washington, DC: American Psychiatric Association, 1997. 
35. Corapcioglu A, Aydemir O, Yildiz M. Structured Clinical Interview for DSM-IV (SCID-I) Turkce Formu. First ed., Ankara: Hekimler Yayin Birligi, 1999.

36. First MB, Gibbon M, Spitzer RL, Williams JBW, Benjamin LS. Structured Clinical Interview for DSM-IV Axis II Personality Disorders (SCID-II). First ed., Washington, DC: American Psychiatric Association, 1997.

37. Coskunol H, Bagdiken I, Sorias S, Saygili R. SCID-II Turkce versiyonunun gecerlik ve guvenilirligi. Turk Psikol Derg 1994; 9: 26-29.

38. Beck AT, Epstein N, Brown G, Steer RA. An inventory for measuring clinical anxiety: Psychometric properties. J Consult Clin Psychol 1988; 56: 893-897.

39. Ulusoy M, Sahin N, Erkmen H. Turkish Version of The Beck Anxiety Inventory: Psychometric properties. J Cogn Psychother 1998; 12: 28-35.

40. Beck AT. An inventory for measuring depression. Arch Gen Psychiatry 1961; 4: 561-571.

41. Hisli N. Beck Depresyon Envanterinin üniversite öğrencileri için geçerliliği, güvenirliği. Psikoloji Derg 1989; 7: 3-13.

42. Baker F, Denniston M, Zabora J, Polland A, Dudley WN. A POMS short form for cancer patients: Psychometric and structural evaluation. Psycho-Oncology 2002; 11: 273-281.

43. Barker-Collo SL. Culture and validity of the Symptom Checklist90-Revised and Profile of Mood States in a New Zealand student sample. Cultur Divers Ethnic Minor Psychol 2003; 9: 185-196.

44. O'Connor PJ. Evaluation of four highly cited energy and fatigue mood measures. J Psychosom Res 2004; 57: 435-441.
45. Boyle GJ. A cross-validation of the factor structure of the Profile of Mood States: Were the factors correctly identified in the first instance? Psychol Rep 1987; 60: 343-354.

46. Gibson SJ. The measurement of mood states in older adults. J Gerontol 1997; 52: 167-174.

47. Guadagnoli E, Mor V. Measuring cancer patients' affect: Revision and psychometric properties of the Profile of Mood States (POMS). Psychol Assess 1989; 1: 150-154.

48. Kaye JM, Lawton MP, Gitlin LN, Kleban MH, Windsor LA, Kaye D. Older people's performance on the Profile of Mood States (POMS). Clin Gerontol 1988; 7: 35-56.

49. Norcross JC, Guadagnoli E, Prochaska JO. Factor structure of the Profile of Mood States (POMS): Two partial replications. J Clin Psychol 1984; 40: 1270-1277.

50. Reddon JR, Marceau R, Holden RR. A confirmatory evaluation of the Profile of Mood States: Convergent and discriminant item validity. J Psychopathol Behav Assess 1985; 7: 243-259.

51. Tunis SL, Golbus MS, Copeland KL, Fine BA, Rosinsky BJ, Seely L. Normative scores and factor structure of the Profile of Mood States for women seeking prenatal diagnosis for advanced maternal age. Educ Psychol Meas 1990; 50: 309-324.

52. Thorndike EL, Lorge I. The teacher's word book of 30,000 words. First ed., New York: Teachers College Press, 1944

53. Albrecht RR, Ewing SJ. Standardizing the administration of the Profile of Mood States (POMS): Development of alternative word lists. J Pers Assess 1989; 53: 31-39. 


\section{Appendix 1. Duygudurumları Profili (DP)}

İsim:

Cinsiyet:

Yaş:

Tarih:

Aşağıda insanların sahip oldukları duygu ya da hisleri tanımlayan 58 kelimelik bir liste yer almaktadır. Lütfen bunların her birini dikkatle okuyunuz. Daha sonra, bu günde dâhil olmak üzere geçtiğimiz hafta içinde sizin bu duyguları ne derecede hissediyor olduğunuzu tanımlayan en uygun yanıtı işaretleyiniz.

\begin{tabular}{|c|c|c|c|c|c|c|c|c|c|c|}
\hline \multicolumn{6}{|c|}{ Her bir numara şu anlama gelmektedir: } & 32.Cesaretsiz & 0 & 1 & 2 & 3 \\
\hline \multicolumn{6}{|c|}{$0=$ Asla } & 33.Gücenmiş & 0 & 1 & 2 & 3 \\
\hline \multicolumn{6}{|l|}{$1=$ Çok az } & 34.Sinirli & 0 & 1 & 2 & 3 \\
\hline \multicolumn{6}{|l|}{$2=$ Orta derecede } & 35.Yalnız & 0 & 1 & 2 & 3 \\
\hline \multicolumn{6}{|l|}{$3=$ Oldukça fazla } & 36.Zavallı & 0 & 1 & 2 & 3 \\
\hline \multicolumn{6}{|l|}{ 4=Aşırı } & 37.Sersem & 0 & 1 & 2 & 3 \\
\hline & & & & & & 38.Neşe saçan & 0 & 1 & 2 & 3 \\
\hline 2.Gergin & 0 & 1 & 2 & 3 & 4 & 39.Acı duyan & 0 & 1 & 2 & 3 \\
\hline 3.Öfkeli & 0 & 1 & 2 & 3 & 4 & 40.Tükenmiş & 0 & 1 & 2 & 3 \\
\hline 4.Yıpranmış & 0 & 1 & 2 & 3 & 4 & 41.Sıkıntılı & 0 & 1 & 2 & 3 \\
\hline 5.Mutsuz & 0 & 1 & 2 & 3 & 4 & 42.Kavgacı & 0 & 1 & 2 & 3 \\
\hline 7.Hayat dolu & 0 & 1 & 2 & 3 & 4 & 44.Kasvetli & 0 & 1 & 2 & 3 \\
\hline 8.Şaşkın & 0 & 1 & 2 & 3 & 4 & 45.Çaresiz & 0 & 1 & 2 & 3 \\
\hline 9.Yaptıklarına üzgün & 0 & 1 & 2 & 3 & 4 & 46.Tembel & 0 & 1 & 2 & 3 \\
\hline 10.Keyifsiz & 0 & 1 & 2 & 3 & 4 & 47.İsyankar & 0 & 1 & 2 & 3 \\
\hline 11.Olanlara kaygısız & 0 & 1 & 2 & 3 & 4 & 48.Yardımsız & 0 & 1 & 2 & 3 \\
\hline 12.Hırçın & 0 & 1 & 2 & 3 & 4 & 49.Bezgin & 0 & 1 & 2 & 3 \\
\hline 14.Mahzun & 0 & 1 & 2 & 3 & 4 & 50.Şaşırmış & 0 & 1 & 2 & 3 \\
\hline 15.Aktif & 0 & 1 & 2 & 3 & 4 & 51.Tetikte & 0 & 1 & 2 & 3 \\
\hline 16.Sabırsız & 0 & 1 & 2 & 3 & 4 & 52.Aldatılmış & 0 & 1 & 2 & 3 \\
\hline 17.Suratı asık & 0 & 1 & 2 & 3 & 4 & 53.Kıggın & 0 & 1 & 2 & 3 \\
\hline 18.Hüzünlü & 0 & 1 & 2 & 3 & 4 & 54.Becerikli & 0 & 1 & 2 & 3 \\
\hline 19.Çalışkan & 0 & 1 & 2 & 3 & 4 & 56.Enerji dolu & 0 & 1 & 2 & 3 \\
\hline 20.Panik yapan & 0 & 1 & 2 & 3 & 4 & 57.Aksi huylu & 0 & 1 & 2 & 3 \\
\hline 21.Umutsuz & 0 & 1 & 2 & 3 & 4 & 58.Değersiz & 0 & 1 & 2 & 3 \\
\hline 22.Rahat & 0 & 1 & 2 & 3 & 4 & 59.Unutkan & 0 & 1 & 2 & 3 \\
\hline 23.Bir şeye değmeyen & 0 & 1 & 2 & 3 & 4 & 60.Dikkatsiz & 0 & 1 & 2 & 3 \\
\hline 24.Kinci & 0 & 1 & 2 & 3 & 4 & 61.Çok korkmuş & 0 & 1 & 2 & 3 \\
\hline 26.Huzursuz & 0 & 1 & 2 & 3 & 4 & 62.Suçlu & 0 & 1 & 2 & 3 \\
\hline 27.Hareketsiz duramayan & 0 & 1 & 2 & 3 & 4 & 63.Dinç & 0 & 1 & 2 & 3 \\
\hline 28.Konsantre olamama & 0 & 1 & 2 & 3 & 4 & 64.Herşeyle ilgili şüpheci & 0 & 1 & 2 & 3 \\
\hline 29.Yorgun & 0 & 1 & 2 & 3 & 4 & 65.Ne yapacağını bilemeyen & 0 & 1 & 2 & 3 \\
\hline 31.Usanmış & 0 & 1 & 2 & 3 & 4 & & & & & \\
\hline
\end{tabular}

Önemli not: Ölçeğin burada 58 maddelik, 6 faktörlü çözümü sunulmuş olup hiçbir faktöre uymayan 7 madde [(1) Arkadaşça, (6) İyimser, (13) Nazik, (25) Sempatik, (30) Yardımsever, (43) Yumuşak huylu ve (55) Tevekkül eden] dişlanmıştır. 